\title{
Use of the in vitro model for the evaluation of toxic effects of metabolites produced by fungi
}

\author{
Z. Kováčiková ${ }^{1}$, E. Piecková ${ }^{1}$, E. Tátrai ${ }^{2}$, Z. Pivovarová ${ }^{1}$ \\ $\&$ M. Mataušic-Pišl ${ }^{3}$ \\ ${ }^{1}$ Slovak Medical University, Bratislava, Slovakia \\ ${ }^{2}$ National Institute of Environmental Health, Budapest, Hungary \\ ${ }^{3}$ Institute of Medical Research and Occupational Health, \\ Zagreb, Croatia
}

\begin{abstract}
There are several reports about chronic intoxications, allergies or other pulmonary health problems of dwellers (especially babies) and workers from buildings contaminated with microfungi. Material from presented work was collected during the study of indoor fungal colonization of mouldy dwellings and public buildings in Slovakia. The isolated fungi were cultivated for 10 days in liquid media and their products - both endo- and exometabolites were isolated. The metabolites from four isolates of Stachybotrys chartarum, two of Aspergillus versicolor and one of Penicillium chrysogenum were used. Their effects were studied in vitro on rat alveolar epithelial type 2 cells, from the toxicological point of view one of the most important lung cells type. Type 2 cells were cultured for 20 hours in DMEM and then they were exposed for 24 hours to various concentrations of metabolites. The toxicity was evaluated by staining the cells for alkaline phosphatase which is a marker for this cell type. The toxic effect of metabolites from all isolates of Stachybotrys chartarum was dose dependent, there were differencies in the extent of cytotoxicity. From the tested microorganisms Stachabotrys chartarum and Aspergillus versicolor showed high toxic effects (Stachybotrys higher than Aspergillus), while Penicillium chrysogenum only minor toxic effects in this test.

Keywords: alveolar epithelial type 2 cells, Stachybotrys chartarum, Aspergillus versicolor, Penicillium chrysogenum, metabolites.
\end{abstract}




\section{Introduction}

Exposure to microbes is recognized as a potential cause of inflammation related health problems among occupants of mouldy buildings. The current understanding is that the microbial growth affects the indoor air quality and occupants are exposed to biological pollutants but there are not information which components of the microbial flora are most harmful [1]. During a 5-year study of indoor fungal colonization of mouldy dwellings and public buildings in Slovakia, 147 wall scrapings, house dust and air samples were collected [2]. From recovered isolates of various microfungi 4 isolates of Stachybotrys chartarum, 2 isolates of Aspergillus versicolor and 1 of Penicillium chrysogenum were chosen for this study. As inhalation route is the possible entry of microorganisms or their products our attention must be focused on the lung. Lung is a very complex organ, it consists only in the bronchoalveolar region from more than 40 cell types [3]. Alveolar epithelial type 2 cells belong (from the toxicological point of view) to the most important cells. Type 2 cells are cuboidal cells with lamellar body structures that cover approximately $5 \%$ of alveolar surface area and play a critical role in preserving the functional integrity of the alveolar surface [4]. Histochemical staining revealed that in the bronchoalveolar region of lung alkaline phosphatase is uniquely associated with the apical portion of alveolar type 2 cells and therefore alkaline phosphatase is used as marker for this type of cells. In presented study we used this marker for studying the effect of metabolites produced by fungi on alveolar epithelial type 2 cells isolated from rats.

\section{Materials and methods}

\subsection{Isolation of fungal metabolites}

Stachybotrys chartarum, Aspergillus versicolor and Penicillium chrysogenum were inoculated on a liquid medium (2\% yeast extract and $10 \%$ sucrose) and cultivated at $25^{\circ} \mathrm{C}$ for 10 days. The fermented cultures were filtered through Whatman paper No. 5 under reduced pressure. Both media and biomass filter cakes were collected. Separated biomass (endometabolites) and cultivation media (exometabolites) were extracted twice with chloroform, extracts were concentrated in vacuo to dryness (Buchi 461 Water Bath, Buchi RE 121 Rotavapor, Flavil, Switzerland).

\subsection{Isolation and cultivation of alveolar epithelial type 2 cells}

Male Wistar rats (Velaz, Prague, Czech Republic) of about 180-200 g were used in these experiments. Alveolar epithelial type 2 cells were isolated according to Richards et al. [5] and Hoet et al. [6]. Cells were cultivated under standard laboratory conditions in Dulbecco's Modified Eagles' Medium (DMEM) with $5 \%$ fetal bovine serum (FBS) for 20 hours in the atmosphere of 5\% carbon dioxide in air at $37^{\circ} \mathrm{C}$ before exposure to metabolites. The metabolites were 
applied at various concentrations in fresh medium with 5\% FBS and the cultivation continued for another 24 hours. After finishing the cultivation the medium was withdrawn, cells were washed twice with phosphate buffered saline and the staining for alkaline phosphatase was performed.

\subsection{Alkaline phosphatase staining (APh)}

The cells were stained by the adapted method of Bingle et al [7]. One tablet of naphtol AS-TR phosphate was dissolved in $10 \mathrm{ml}$ deionised water and 3 tablets of Fast Red RC were dissolved in $5 \mathrm{ml}$ TRIS-HCl buffer $\mathrm{pH} \mathrm{8.5.} \mathrm{Cells} \mathrm{were}$ stained in a mixture of $5 \mathrm{ml} \mathrm{AS-TR}$ and $5 \mathrm{ml}$ Fast Red by incubation for 30 minutes at room temperature. Positive cells were stained bright red. Only cells with 4 or more lamellar bodies were considered to be type 2 cells.

\section{Results}

\subsection{Comparing the number of alkaline phosphatase positive cells after exposure to metabolites from various Stachybotrys chartarum isolates}

Staining of type 2 cells showed that endometabolites from Stachybotrys chartarum decreased the number of alkaline phosphatase positive cells dose dependently. The individual samples differ in the extent of changes. The greatest inhibition was seen in sample 3 (Figure 1).

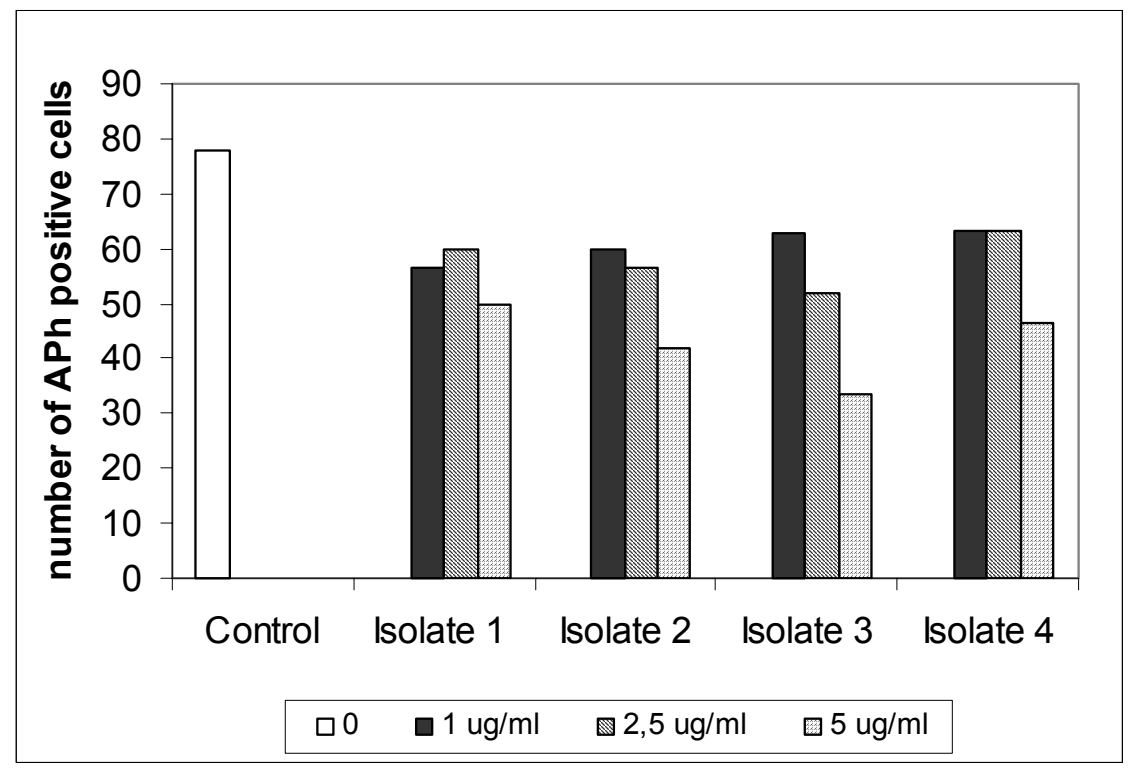

Figure 1: Effect of endometabolites from 4 isolates of Stachybotrys chartarum on alkaline phosphatase positivity of alveolar epithelial type 2 cells after $24 \mathrm{~h}$ in vitro culture. 


\subsection{Effect of metabolites from Aspergillus versicolor on alveolar epithelial type 2 cells}

Results from 24 hours exposure of type 2 cells to metabolites isolated from Aspergillus versicolor are summarized in Figure 2. Both endo- and exometabolites of two isolates were tested. The higher dose $(2 \mu \mathrm{g} / \mathrm{ml})$ of endometabolites showed greater toxicity than the same concentration of exometabolites but the exposure to lower doses exhibited similar effects of both types of metabolites.

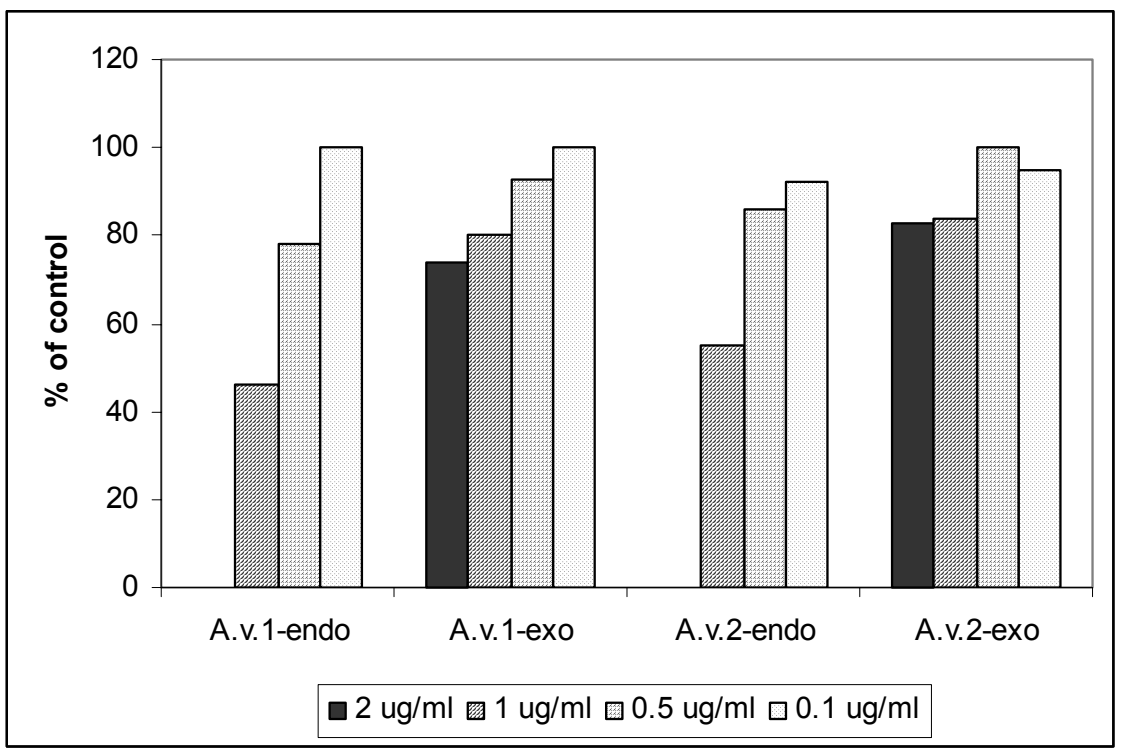

Figure 2: $\quad$ Effect of endo- and exometabolites from 2 isolates of Aspergillus versicolor on alkaline phosphatase positivity of lung epithelial type 2 cells after $24 \mathrm{~h}$ in vitro culture. (A.v.: Aspergillus versicolor; endo: endometabolites; exo: exometabolites.

\subsection{Exposure of alveolar epithelial type 2 cells to metabolites produced by Penicillium chrysogenum}

The pilot study of influence of both endo- and exometabolites from Penicillium chrysogenum on the type 2 cells at the concentration $0.1-2 \mu \mathrm{g} / \mathrm{ml}$ showed that the exposed cells exhibited $85-97 \%$ alkaline phosphatase positivity of the control value.

\section{Discussion}

The aim of the study was to compare the effect of metabolites produced by various fungi isolated from mouldy buildings. In vitro cultured alveolar epithelial 
type 2 cells isolated from rats were used for testing their effect. Metabolites from four different isolates of Stachybotrys chartarum, two of Aspergillus versicolor and one of Penicillium chrysogenum were studied. The effect decreased in order Stachybotrys chartarum, Aspergillus versicolor, Penicillium chrysogenum. The metabolites from all isolates of $S$. chartarum and $A$. versicolor exhibited similar results, their toxic effect was increased dose dependently, they differ only in their extent. There is evidence [8] that microfungi can concurrently produce mixture of metabolites, each of them has different effect and these metabolites may act synergistically what may be the possible explanation for differencies between individual isolates. Metabolites of $P$. chrysogenum showed only minor effect on the alkaline positivity of the type 2 cells. Figure 2 gives evidence that there are differencies between the effect of endo- and exometabolites of $A$. versicolor: the higher concentration of endometabolites were more toxic than the same concentration of exometabolites but at lower concentration (which are more near to the reality) there were not significant differencies. The results were same also in case of $S$. chartarum (unpublished results). There are differencies not only in the effect of particular isolates but also in response of particular lung cell type. In the previous study [9] we have proved that alveolar macrophages are more sensitive to the metabolites produced by $S$. chartarum than type 2 cells.

\section{Acknowledgements}

The study was supported by the Ministry of Health of the Slovak Republic under the project 2005/36-SZU-14 and by EC contract HEAR NAS QLK6-200290945.

\section{References}

[1] Huttunen, K., Hyvärinen, A., Nevalainen, A., Komulainen, H. \& Hirvonen, M.R., Production of proinflammatory mediators by indoor air bacteria and fungal spores in mouse and human cell lines. Environmental Health Perspectives 111 (1), pp.85-92, 2003.

[2] Piecková, E., Hurbánková, M., Pivovarová, Z., Černá, S., Kováčiková, Z., Líšková, A., Wilkins, K. \& Tátrai, E., Toxic effects of Stachybotrys chartarum. Trends in Medical Mycology. $9^{\text {th }}$ Congress of the European Confederation of Medical Mycology and $7^{\text {th }}$ Trends in Invasive Fungal Infection. Amsterdam, pp. 35-36, 2003.

[3] Sorokin, S.P., Properties of alveolar cells and tissues that strengthen alveolar defences. Archives of Internal Medicine 126, pp. 450-163, 1970.

[4] Castranova, V., Rabovsky, J., Tucker, J.H. \& Miles, P.R., The alveolar type II epithelial cell: a multifunctional pneumocyte. Toxicology and Applied Pharmacology 93, pp.472-483, 1988.

[5] Richards, R.J., Davies, N., Atkins, J. \& Oreffo, V.I.C., Isolation, biochemical characterisation and culture of lung type II cells of the rat. Lung 165, pp. 143-158, 1987. 
[6] Hoet, P.M.H., Lewis, C.P.L., Demedts, M. \& Nemery, B., Putrescine and paraquat uptake in human lung slices and isolated type II pneumocytes. Biochemical Pharmacology 48, pp.517-524, 1994.

[7] Bingle, L., Bull, T.B., Fox, B., Guz, A., Richards, R.J. \& Tetley, T.D., Type II pneumocytes in mixed cell culture of human lung: a light and electron microscopic study. Environmental Health Perspectives 85, pp. 71-80, 1990.

[8] Andersson, M.A., Nikulin, M., Koljalg, U., Andersson, M.C., Rainey, F., Reijula, K., Hintikka, E.L. \& Salkinoja-Salonen, M., Bacteria, molds, and toxins in water damaged building materials. Applied and Environmental Microbiology 63, pp. 387-393, 1997.

[9] Kováčiková, Z., Tátrai, E., Piecková, E., Tulinská, J., Pivovarová, Z., Mataušic-Pišl, M., Kuricová, M. \& Wsolová, L., In vitro study of toxic effects of Stachybotrys chartarum metabolites on lung cells. Alternatives to Laboratory Animals, 2007 (in press). 